21

\title{
Thermal Alteration to the Body
}

Tim J.U. Thompson, David Gonçalves, Kirsty Squires and Priscilla Ulguim

\subsection{Introduction}

There are few taphonomic processes that have as great and significant an effect on the body as burning. This highly transformative process can result in a broad range of changes to the soft and hard tissues, which in turn make recovery in the field and subsequent analysis extremely challenging. Within the archaeological and forensic contexts, it is not surprising that many view burned bone as being the most difficult of conditions to study - and as such, there are few researchers in the forensic or archaeological arenas who are working routinely with this material.

Specific terms used in relation to burned remains are discussed in more detail by Thompson (2009; 2015), but the key point is that while many terms are used interchangeably, they do have specific meanings. Thus 'burned remains' refers to remains that have been exposed to fire, 'cremated remains' refer to bodies that have been burned as part of a funerary process, and 'calcined remains' refer to those that have undergone alterations including calcination (thus suggesting an intense burning environment). These subtle differences in terms have important implications when describing the broader context of burning.

This chapter will explore the myriad ways in which heating and burning alters the human body, how these alterations influence our ability to successfully analyse the remains, and possible future directions for research and practice.

\subsection{Soft Tissue Changes}

Heating and burning have a dramatic effect on the whole body, but the soft tissues are particularly susceptible to damage. The source of the heat can have a great influence on the speed and extent of this damage. For example, a modern crematorium can reach temperatures of over $1,000^{\circ} \mathrm{C}$ with optimised air flow, whereas a fire in a garden may only reach $500^{\circ} \mathrm{C}$ and be more susceptible to local environmental weather. As the most external and superficial of the soft tissues, the skin will be affected first by fire. The exposure of the skin to heat causes the tissue to dehydrate, which results in shrinkage and splitting. This is problematic in the forensic context since this splitting may mimic non-heat related trauma, or may worsen peri-mortem damage. Splitting of the skin then speeds up the damage to the more internal structures. Hair and nails will also be damaged by the fire and melting (or 'clubbing') of these structures can occur. Following destruction of the skin, the muscles are exposed to the heat. As with the skin, the muscles experience shrinkage and contraction due to dehydration and ultimately will be physically destroyed by the heating. 
Before this point, the contraction of the muscles will result in the well-documented 'pugilistic attitude' position whereby the upper and lower limbs flex at the joints, presenting the body in a fighter's position (Symes et al. 2008). Historically this was used to determine that the individual was alive and struggling at the time of the fire, but has since been proven to be a result of dehydration and contraction of the muscles. The internal viscera will become directly exposed to the heat and fire once the skin and muscles have been destroyed. The heat will cause these organs to contract and they will also shrink in size. Note as well that heat will affect the body as a result of the fire, but also because of the heated air and gases that the victim will breathe into the body if still alive, thus damaging the respiratory system directly. Presence of this form of damage has been used to determine whether the victim was alive or dead during the fire event. When heating of the brain occurs, it is possible for bloodstains to be left on the internal surfaces of the cranial bones. This is referred to as a heat haematoma and can be misinterpreted as being the result of violence. Blood is also affected by heat. First, the proximity of the fire can cause the physical destruction of the blood cells. Second, the composition of the blood can be altered by the toxins breathed in by the victim. The classic example is with the build-up of carbon monoxide.

Note that the damage to the soft tissue will not occur uniformly across the body, but is rather determined by proximity to the heat source. Forensically this is useful since it allows for the fire scene to be reconstructed and body position to be determined relative to the fire through an analysis of thermal damage across the body (DeHaan 2008; Symes et al. 2008). Differences in proximity to the heat source are evident through the gradient of expression of heat-induced features, such as colour change and those discussed below.

While it is thought that the destruction to the soft tissues is relatively straightforward, heat-induced changes to the hard tissues are complicated and multifactorial. Nonetheless, a fuller understanding of these changes does allow one to comment confidently on the context of death or deposition.

\subsection{Hard Tissue Changes}

The changes to the hard tissues arguably have a greater impact on our ability to determine the identity of the deceased and the manner and context of death. Bone and teeth undergo four stages of transformation (Mayne Correira, 1997; Thompson 2004):

1) Dehydration occurs when the water is lost from the bone

2) Decomposition occurs when the organic material in the bone is lost

3) Inversion follows and marks the beginning of the changes in the inorganic component of the bone

4) Fusion, the final phase, occurs when the inorganic crystals start to coalesce and reorder

There is some debate as to the exact point at which these four stages will occur, and they are likely to alter as a result of a number of variables including temperature, duration of burning, oxygen supply, presence of clothing, etc. The Fusion stage has a considerable effect on our methods of osteoprofiling (constructing a biological identity) from the remains and this can occur in an average house fire setting (Thompson 2004).

In addition to these four general stages of transformation, there are a number of more specific heat-induced changes that occur in bone and can be linked strongly with the transformations detailed above. However, the two most significant of these phases are the second (Decomposition) and the fourth (Fusion). The loss of the organic material and the restructuring of the inorganic phase have been shown to be the precursor for the heat-induced changes that are routinely recorded on burned bone (Thompson 2005). These two changes have thus been labelled as primary-level heat-induced 
changes. All other heat-induced changes, such as changes to colour and the propagation of fractures are termed secondary-level changes, as they are the result of the primary-level changes (Thompson 2005, 2009).

While it may seem that these changes are so extensive that they preclude any deep understanding of a given set of burned human remains, this is not the case. The majority of information available to an anthropologist from unburned remains is also available from burned remains, but this requires greater effort and interpretation because of these overlapping changes.

\subsubsection{Colour Change}

Heat-induced colour change in bone and teeth is a macroscopic, secondary-level change resulting from chemical and physical alterations within the bone structure that occur progressively during heating (Thompson 2004). Colour data from forensic contexts enables the reconstruction of details of the combustion process through assessment of burn intensity and variability. As a highly visible indicator of heating, with regular stages, colour change has formed part of burned bone analysis since early studies (Baby 1954). Subsequent experimental research has provided a link between such colour change and primary-level changes in the bone structure (Bonucci and Graziani 1975; Shipman et al. 1984). However, interpretation is challenged by variables including other taphonomic processes, and the assessment of the variation of colour across surfaces (Mayne Correia 1997). Therefore, this approach requires a systematic and objective recording system, and is best employed in combination with other analytical methods (Devlin and Herrmann 2008; Sandholzer 2014; Shipman et al. 1984; Walker et al. 2008).

As bone is heated, increasing intensity and duration cause changes in the organic and inorganic phases of the bone structure and chemistry resulting in colour alterations from pale yellow through orange shades to brown, black, grey and then white (Bonucci and Graziani 1975; Devlin and Herrmann 2008; Ellingham et al. 2015; McCutcheon 1992; McKinley 2000; Munro et al. 2007; Nicholson 1993; Shipman et al. 1984; Thurman and Wilmore 1980; Ubelaker 1978) (Table 21.1). Similar changes have been recorded in tooth structures (Beach et al. 2008; Kharkanis et al. 2009; Sandholzer 2014; Sandholzer et al. 2014; Schmidt 2008). This colour change is mainly associated with the decomposition phase as organic content is reduced, while extended burning at higher temperatures usually results in white calcined bones indicating removal of organic matter and possible inversion and fusion in accordance with linked primary-level changes in bone (Ellingham et al. 2015; Thompson 2004). Equivalent colours may be attained through different temperature and duration combinations, meaning that colour is more useful for assessing intensity rather than specific temperatures (Duday 2009; Sandholzer 2014; Shipman et al. 1984). Such research has been successfully applied in anthropological and archaeological contexts, for example, Harvig et al. (2013) in part used colour to determine that bones in an Iron Age house were probably not heated within a pyre structure due to their interpretation of burn intensity. Other studies have used burn variation across articular surfaces to assess whether bones were burnt when articulated or disarticulated (Wolf 2011). Furthermore, colour evidence comprises an important indicator for the survival of organics for stable isotope and DNA analysis (Harbeck et al. 2011; Schwark et al. 2011; Walker et al. 2008).

Variables influencing colour change include exposure, duration, local environment, oxygen availability and fuel type and quantity. Fuel and oxygen availability imply differing combustion levels, heat release and flux rates (DeHaan 2002, 2008; Walker and Miller 2005; Walker et al. 2008). Meanwhile, exposure may be influenced by body position and condition, including the amount of soft tissue, blood and haemoglobin, marrow, fat and moisture which can protect bones and teeth and cause physical and chemical reactions during combustion (Binford 1963; DeHaan and Nurbakhsh 2001; Eckert et al. 1988; Schmidt 2008; Symes et al. 2008; Walker et al. 2008). In addition, colour may be altered 
Table 21.1 Colour mapping of experimental colour data on burned bone with increasing temperature and primary level phase. Decomposition encompasses the change from yellow/brown to calcined white. 1: Dehydration, 2: Decomposition, 3: Inversion, 4: Fusion. YE: Yellow, BR: Brown, BL: Black, GR: Grey, WH: White.

\begin{tabular}{|c|c|c|c|c|c|c|c|c|}
\hline & Shipman et al. 1984 & Nicholson 1993 & Munro et al. 2007 & Walker et al. 2008 & Pha & (Th & pso & 004) \\
\hline${ }^{\circ} \mathrm{C}$ & $\begin{array}{l}\text { Defleshed Animal } \\
\text { Bone/Teeth }\end{array}$ & $\begin{array}{c}\text { Defleshed } \\
\text { Animal Bone }\end{array}$ & $\begin{array}{l}\text { Defleshed } \\
\text { Animal Bone }\end{array}$ & $\begin{array}{c}\text { Fresh Defleshed } \\
\text { Human Bone } \\
\text { (Femur) }\end{array}$ & 1 & 2 & 3 & 4 \\
\hline 100 & & & & & & & & \\
\hline 150 & & & & & & & & \\
\hline 200 & YE & BR & $\mathrm{YE} / \mathrm{BR}$ & BR & & & & \\
\hline 250 & YE & BR & & & & & & \\
\hline 300 & & BL & BR & BL & & & & \\
\hline 350 & BR & & & & & & & \\
\hline 400 & & GR & $\mathrm{BL}$ & $\mathrm{BR} / \mathrm{GR}$ & & & & \\
\hline 450 & BR & & & & & & & \\
\hline 500 & & GR & & $\mathrm{BR} / \mathrm{GR}$ & & & & \\
\hline 550 & $\mathrm{BL}$ & & & & & & & \\
\hline 600 & & GR & GR/YE & GR & & & & \\
\hline 650 & WH & & & & & & & \\
\hline 700 & WH & WH & $\mathrm{WH} / \mathrm{GR}$ & GR & & & & \\
\hline 750 & WH & & & & & & & \\
\hline 800 & WH & WH & WH & WH/GR & & & & \\
\hline 850 & WH & & & & & & & \\
\hline 900 & & WH & WH & WH & & & & \\
\hline 950 & WH & & & & & & & \\
\hline 1000 & & & & WH & & & & \\
\hline \multicolumn{9}{|l|}{1050} \\
\hline 1100 & & & & WH & & & & \\
\hline
\end{tabular}


by other materials in the combustion environment, for example burning in proximity to metals may produce greens, yellows, pinks and reds (Dunlop 1978).

Bones may also be burnt or heated in natural or man-made fires prior to or following deposition; this could include cooking (Roberts et al. 2002; Subías 2002) or alteration of buried bone (Bennett 1999; Stiner et al. 1995). Bennett (1999) showed that subsurface colour change occurs in a similar fashion to surface burning, but that bone surface colour appears more uniform, most likely due to a more consistent exposure through the insulation, dispersal of the heat through the ground, and consistency of the burial medium.

Other activities can result in non-heat related bone colour change. In a recent archaeological study, microscopic analysis of black-coloured bones indicated that the colour resulted from treatment with bitumen, rather than heat-induced change, and this was interpreted as part of a funerary practice involving dismembering prior to burial (Argáez et al. 2011). Colour change similar to burning could apply if other substances are applied, for example ochre (hydrated iron oxide). In burial contexts, bone colour can also be altered by soil staining, $\mathrm{pH}$ level and the presence of trace elements (Oakley 1954; Shahack-Gross et al. 1997; Svenson and Wendel 1965). Finally, conservation may impact colour, including the application of consolidants such as paraloid or cyanoacrylate to prevent fragmentation of fragile elements. The liquid solution can cause darkening and reflective surface sheen or gloss, and if bones are insufficiently cleaned, any organic or inorganic materials on the bone surface will be fixed in place (Ulguim 2015).

The complexity and variation in bone surface colour change led Mayne Correia (1997) to question the value of any single bone colour in interpreting fire dynamics. However, colour data can be of value when detailed information on patterning across surfaces is collected. The transition of colours across elements represents a 'process signature' (Symes et al. 2008), which can be used to reconstruct past events. In order to assess this complexity a robust, repeatable and objective method is required. Shipman et al. (1984) employed a standardised method for assessing bone colour, using manual comparison with the Munsell Soil Colour Chart, which has become a standard assessment method (Kharkanis et al., 2009; McCutcheon 1992; Munro et al. 2007). Shipman et al. (1984) did note the limitations in human colour perception and objectivity, and although the Munsell system allows more systematic recording of colour, it is a system designed for soil colour analysis, and can only provide a subjective assessment which is influenced by material state and light conditions. Additionally, the non-continuous nature of the data does not allow for easy comparison (Wolf 2011). Researchers are now investigating the use of different colour models such as RGB (Red-Green-Blue) and CIE "L*a*B* (a model defined by CIE, the Commission Internationale de l'Eclairage, with values for $L^{*}$ : lightness, $a^{*}$ : red-green values, $b^{*}$ : yellow-blue values which locates colour on a three-dimensional axis), together with digitised recording methods such as flat-bed scanners, digital photography and spectrophotometers to reduce subjectivity and permit fine-grained and statistical analysis of colour change and surface variation (Devlin and Herrmann 2008; Ulguim 2015; Walker et al. 2008) (Table 21.2).

Devlin and Herrmann (2008) recorded colour in cremated human remains at the Walker-Noe archaeological site using CIE L* $\mathrm{a}^{*} \mathrm{~B}$, with spectrophotometers to collect accurate colour data which could be analysed statistically. When combined with accurate fragment location and identification in a GIS system, this accounted for variation across surfaces (Devlin and Herrmann 2008). Cranial fragments exhibited the whitest colouring with elevated yellow levels, indicating increased intensity, while appendicular bone provided lower white levels. They also noted the effect of soil staining occurring in the depositional environment. Ulguim (2015) applied RGB analysis to cremated remains, in this case a computer program captured RGB colours from a minimum of three points on bone surfaces to provide more objective information about burn patterning. Walker et al. (2008) used a different approach, creating average RGB analysis for the scanned bone surfaces. Cluster analysis of burnt 
Table 21.2 Some advantages and disadvantages of commonly used colour systems.

\begin{tabular}{|c|c|c|c|}
\hline $\begin{array}{l}\text { Colour } \\
\text { Recording } \\
\text { System }\end{array}$ & Advantages & Disadvantages & $\begin{array}{l}\text { Application to Burnt } \\
\text { Bones and Teeth }\end{array}$ \\
\hline Munsell & - Systematic and Standardised & $\begin{array}{l}\text { - Subjective } \\
\text { - Cannot easily account for surface } \\
\text { colour variation } \\
\text { - Developed for soil colour analysis } \\
\text { - Colour coding difficult for statis- } \\
\text { tical manipulation }\end{array}$ & $\begin{array}{l}\text { Shipman et al. } \\
1984\end{array}$ \\
\hline RGB & $\begin{array}{l}\text { - Systematic and Standardised } \\
\text { - Objective } \\
\text { - Quantifiable and easily com- } \\
\text { parable }\end{array}$ & $\begin{array}{l}\text { - Requires post-processing digital } \\
\text { photograph calibration and anal- } \\
\text { ysis or expensive equipment }\end{array}$ & $\begin{array}{l}\text { Walker et al. 2008; } \\
\text { Ulguim } 2015\end{array}$ \\
\hline CIE L*a* $\mathrm{B}^{*}$ & $\begin{array}{l}\text { - Systematic and Standardised } \\
\text { - Objective } \\
\text { - Quantifiable, and easily com- } \\
\text { parable }\end{array}$ & - Requires expensive equipment & $\begin{array}{l}\text { Devlin and } \\
\text { Herrmann 2008; } \\
\text { Sandholzer 2014 }\end{array}$ \\
\hline
\end{tabular}

tooth surface colour has also been used to further support the premise that colour change is linked to exposure and duration of heating (Sandholzer 2014).

In cases where equipment is lacking, photography may be used as a proxy with data capture via computer, though lighting conditions must be controlled and consistent, and the use of colour palettes for post-processing calibration is essential. Colour change alone cannot provide a full reconstruction of the combustion of burned remains, but it can provide a wealth of data which may be used in conjunction with microscopic analytical techniques such as histomorphology, X-Ray Diffraction and Fourier Transform Infrared Spectroscopy among others. In summary, the use of quantifiable, digitised techniques for such analysis of burnt hard tissues holds further promise for the interpretation of burn conditions and variation.

\subsubsection{Changes in Mass}

As has been noted, heat is a very destructive agent leading in some cases to the pyrolysis of soft tissues, shrinkage or amputation of the extremities (Bohnert et al. 2001). Therefore, full body mass of a cadaver is not at all a useful individualisation feature in forensic cases. On the other hand, the mass of fully skeletonised burned remains may not always be completely devoid of value for bioanthropological assessments. Mass loss occurs due to the removal of water and organics during a burning event (Hiller et al. 2003; Thompson 2004). Natural post-mortem decomposition - which also involves dehydration and organic decay (Collins et al. 2002; Karr and Outram 2012) - may mimic this, so mass loss is not an exclusive heat-induced change. In cases where the identification of heated bone and teeth is uncertain, mass may help confirm that the remains are indeed burned. Since burning exposure often differentially affects a body (Bohnert et al. 1998), this may result in unnatural antimere differences, thus suggesting that a heat-related event occurred (Figure 21.1). Regrettably, complete preservation of both antimeres is not often found when dealing with burned skeletal remains, so this approach certainly has its limitations.

It has been demonstrated that skeletal mass loss varies greatly. It may reach between 30 and $60 \%$ (Enzo et al. 2007; Grupe and Hummel 1991; Hiller et al. 2003; Munro et al. 2007; Person 1996), depending on factors such as temperature and pre-burning condition of the skeletal remains (e.g. 

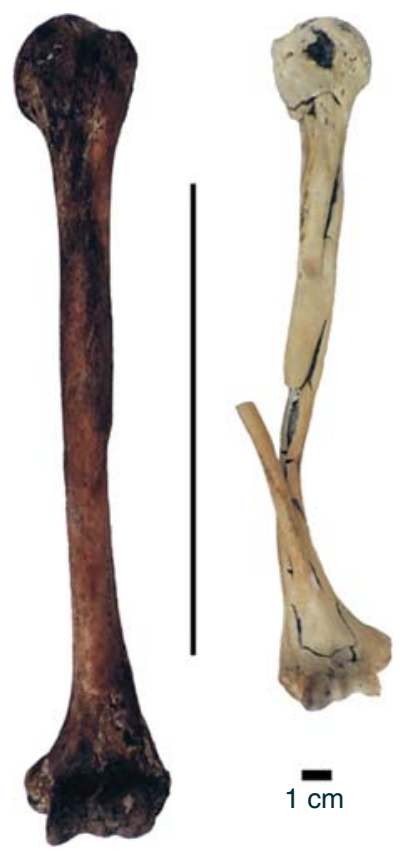

Figure 21.1 Left unburned humerus and right calcined humerus from individual 50 of the XXI Century Identified Collection of the University of Coimbra, subjected to controlled burning. The burned antimere presents substantial shrinkage and mass loss of $35.8 \%$.

fresh vs. dry bones). Nonetheless, under specific circumstances, skeletal mass may still provide important insights (Gonçalves et al. 2015). The major advantage of the skeletal mass approach over other bioanthropological approaches - based on diagnostic features - is that it is not considerably affected by heat-induced fragmentation. Therefore, it can be used in addition to, or as an alternative to, more conventional and reliable methods which usually are more affected by fragmentation.

Studies based on modern crematoria can be used to devise reference data which then allows for skeletal mass to be used as a means of assessing the completeness of the remains or the minimum number of individuals from archaeological and forensic contexts (Gonçalves et al. 2015). Several of these references are available today (Bass and Jantz 2004; Chirachariyavej et al. 2006; Gonçalves et al. 2013a; Malinowski and Porawski 1969; May 2011; McKinley 1993; Van Deest et al. 2011; Warren and Maples 1997). In brief, very small masses are suggestive of incomplete remains, while very large masses are indicative of assemblages containing more than one individual (Duday et al. 2000; Gonçalves et al. 2015). Another potential use proposed for skeletal mass refers to sex estimation, since it is clearly sexually dimorphic (e.g. Malinowski and Porawski 1969; Van Deest et al. 2011). However, the application of this approach to sex estimation requires that burned skeletal remains are assuredly complete, belong to only one individual and are uniformly calcined, something that is often not the case in both forensic and archaeological contexts. Another potential of skeletal mass refers to the detection of preferential selection of specific anatomical parts for subsequent burial. Intentional behaviour can be detected by looking at general trends on the recovery of skeletal elements from the pyre and several methods have been proposed (Duday et al. 2000; Gonçalves et al. 2015; Lenorzer 2006; Richier 2005).

Although useful in some cases, skeletal mass analyses clearly have their own limitations. For instance, references refer only to calcined modern adult individuals (often quite aged) that were cremated in gas-fuelled retorts, so comparison with assemblages presenting other characteristics, such as non-calcined or non-adult remains, is problematic. Also, regional differences in skeletal mass have often been reported previously, so the selection of references is not straightforward, especially 
when dealing with archaeological populations (e.g. Bass and Jantz 2004; Gonçalves et al. 2013a). In addition, the mass of burned skeletal remains may be inflated by non-human aggregated materials and may be scattered or commingled, thus complicating or even precluding any comparative analysis (Kennedy 1996; Warren 2008).

It should also be noted that the dehydration and loss of the organic component which impacts on mass also results in the propagation of fractures. Traditionally, it has been argued that the presence of the soft tissues impacts the nature of the heat-induced fracture pattern. Thus fleshed bones exhibited U-shaped fractures running up the long-axis of the bone, while dry bone displayed rectangular grid-like fracture patters (Thompson 2009). More recent work has questioned the absoluteness of this principle, and argued that it is the presence of collagen within the bone, rather than the outer soft tissues per se, that may be more significant (Gonçalves et al. 2011; Thompson 2015). While the presence of fractures (and the resulting fragmentation) can impede the creation of a biological profile, it does not prevent it. Further work has demonstrated that it is entirely possible to differentiate heat-induced fracturing from that caused by peri-mortem violence (Fairgrieve 2008).

\subsubsection{Dimensional Changes}

Over the years, dimensional change has been one of the most researched heat-induced changes. That is probably because it is a major nuisance to bioanthropology, almost certainly being the most problematic heat-induced obstacle to the application of metric methods (such as those used for age and sex estimation). Although this phenomenon is not as troublesome when dealing with pre-calcined remains (Bradtmiller and Buikstra 1984; Gonçalves 2012; Thompson 2005), its impact on calcined bones and teeth cannot be overlooked.

Dimensional changes, both in the form of shrinkage and expansion, are due to several processes. They are partly caused by dehydration and the removal of the organic component of bones and teeth, but major changes occur only during the fusion stage of heat-induced skeletal transformation when pores previously filled by water and organic material are refilled as a result of the coalescence of the inorganic phase (Thompson 2005). Therefore, all these processes are expected to lead to shrinkage but, somewhat surprisingly and yet inexplicably, bone expansion has also been documented (Gonçalves 2012; Thompson 2005). This further complicates the application of metric methods, which are often used for the assessment of the biological profile. In summary, dimensional bone changes have been documented to vary between a 3.9\% expansion and a $37.7 \%$ shrinkage (Bradtmiller and Buikstra 1984; Gonçalves 2012; Grupe and Herrmann 1983; Herrmann 1976; Holland 1989; Shipman et al. 1984; Strzalko and Piontek 1974; Thompson 2005). To date, the expansion events have been documented only in diaphyseal and epiphyseal dimensions of long bones and in tarsal bones (Gonçalves 2012; Thompson 2005). Sandholzer et al. (2013) observed that shrinkage ranged between $4.8 \%$ in teeth burned at $400^{\circ} \mathrm{C}$ and $32.5 \%$ in teeth burned at $800^{\circ} \mathrm{C}$. Expansion has not yet been recorded for the dentition. Although the organic composition of teeth and bone is somewhat distinct, apparently this does not lead to considerable differences in heat-induced dimensional changes.

The potential of dimensional changes to aid in the identification of burned bone is quite narrow. It requires the presence of both antimeres to allow for a size comparison. If unnatural and significant bilateral asymmetry is present, this suggests that the skeletal remains were subjected to a burning event (Figure 21.1). However, it must be noted that other taphonomic agents can mimic heat-induced shrinkage. This is the case of post-depositional bone that gradually loses water and organic components (Piepenbrink 1986; Lynnerup 2010). In addition, trauma healed in a shortened position, due to overlapping of fractured ends, leads to unusual bilateral asymmetry. Also, pathological conditions such as chondrodysplasia punctata (Waldron 2009) or Ollier disease (Silve and Jüppner 2006) potentially result in the asymmetric shortening of bones. 
Although the impact of dimensional changes on the applicability of metric methods is undeniable, their usefulness is not completely eradicated by heat exposure. In forensic contexts, bodies often display differential burning exposures and parts of the skeleton may not be severely affected by heat due to soft tissue insulation, thus making it possible to use conventional metric references on the skeletal elements. In cases where complete skeletalisation occurred and heat exposure clearly altered the size of bones and teeth - like those involving remains from archaeological contexts - other metric approaches must be used. For instance, a few comparative references have been compiled for sex estimation based on selected calcined remains that were heavily affected by shrinkage (Gonçalves et al. 2013b; Van Vark et al. 1996; Wahl 1996). Other procedures are based on the enlargement of the estimation intervals. For example, the interval for the age at death estimation of foetal burned remains must take into account heat-induced dimensional changes. Adapting the recommendations from Fairgrieve (2008), the bounds of that interval should be formed by:

1) the result of bone measuring taking the maximum heat-induced expansion into consideration (bone measurement*0.039 + bone measurement)

2) the result of bone measuring taking the maximum heat-induced shrinkage into consideration (bone measurement*0.377 + bone measurement)

\subsubsection{Histological Changes}

An essential aspect of analysing burned skeletal remains is an assessment of their macroscopic appearance. However, the study of histological changes that occur to heat-modified bone is equally as valuable. This form of analysis can provide useful information about burning conditions and their effect on skeletal material. Forbes (1941) was one of the first to recognise the value of conducting histomorphological (or thin-section) analysis on human burned bone. However, it was not until Herrmann (1977) conducted histomorphological analyses on archaeological material that this technique received the recognition that it deserved. Since then, the histological character of burned archaeological and modern bone has been examined as a means of understanding the microscopic changes that occur in bone as a result of burning processes (Bradtmiller and Buikstra 1984; Cattaneo et al. 1999; Fernández Castillo et al. 2013a, 2013b; Hanson and Cain 2007; Squires et al. 2011).

Histological changes of heat-modified skeletal remains are assessed by cutting thin-sections of bone and are subsequently examined under a microscope using plain polarised light and cross polarised light (Figures 21.2 and 21.3). There are many factors that can influence the histological changes to burned bone, such as the type of skeletal element, position of the body, temperature and duration of a fire. The microstructure of burned bone from archaeological and forensic contexts can be compared
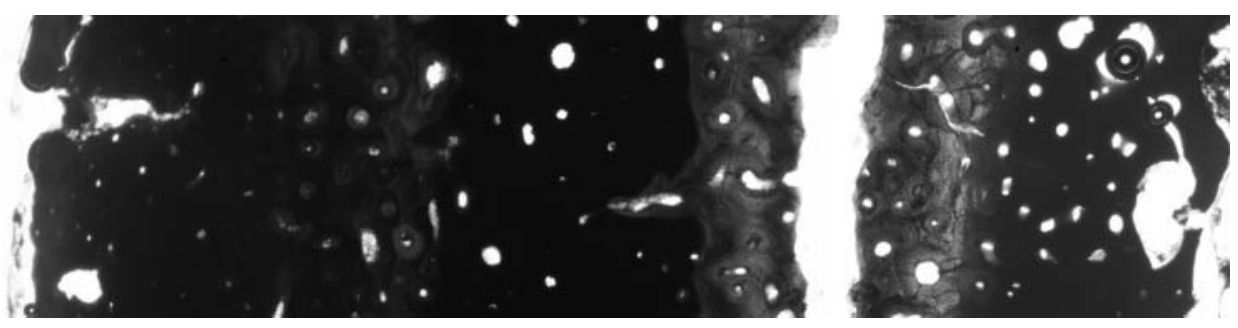

Figure 21.2 Histological detail of a cremated femur fragment from burial EL76NN (FN 549) from the Elsham (North Lincolnshire) cemetery seen under plane polarised light (Source : Reprinted with permission of North Lincolnshire Museum). 


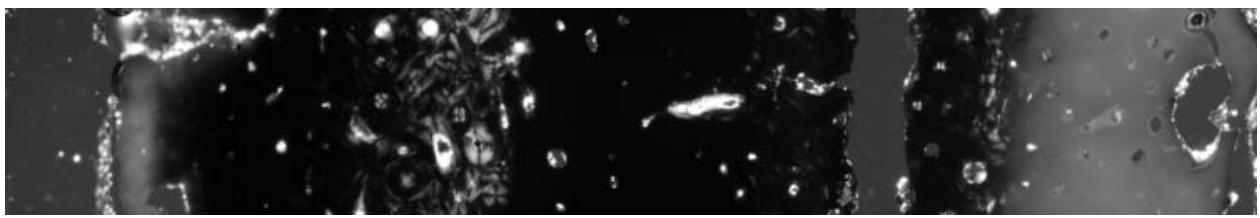

Figure 21.3 Histological detail of a cremated femur fragment from burial EL76NN (FN 549) from the Elsham (North Lincolnshire) cemetery seen under cross polarised light (Source : Reprinted with permission of North Lincolnshire Museum).

to experimental specimens, where temperature and conditions of burning are known, as a means of obtaining detailed information about burning environment (Squires 2015). It is widely recognised that increased temperatures and longer burning times result in bone with decreased organic content and increased fusion of inorganic bone mineral (hydroxyapatite), particularly when heated in excess of $700^{\circ} \mathrm{C}$ (Herrmann, 1977) - and although evident histologically, this technique is rarely employed by osteoarchaeologists and forensic anthropologists.

Shipman et al. (1984) noted that an examination of the histological changes to heat-modified bone is more accurate than relying on bone colour alone, although in most instances the colour of bone and its histological character correspond extremely well (Squires 2011). For example, white calcined bones with no microstructure and complete fusion of hydroxyapatite crystals indicates high intensity burning. However, there are instances where discrepancies occur. A good example of this was identified during the analysis of cremated human remains from the early Anglo-Saxon cemetery of Elsham (North Lincolnshire). Six out of 16 (38\%) samples showed varying degrees of disagreement between the macroscopic appearance and the histological changes of cremated bone (Squires 2011). These observations all indicate that reducing conditions played a key role in the macroscopic appearance of bone fragments, whereas an examination of histological changes provided an insight into burning intensity. Therefore, when assessing burned skeletal remains, temperature, duration and oxidising conditions of a fire are of equal importance when considering the histological appearance of burned bone.

Unfortunately, the time-consuming nature of preparing thin-section samples often discourages the study of histological changes of burned bone (McKinley 1994). Sections of bone need to be extremely thin to identify key histological features through a microscope. Furthermore, heating bone results in dehydration and the loss of organic components, making bone more brittle and fragile. Consequently, cutting thin-sections is challenging, as samples frequently crumble during the initial stages of sample preparation. Therefore, the cortical bone of long bones should be employed when studying histological changes, owing to the more durable nature of these skeletal elements.

\subsubsection{Crystalline and Elemental Changes}

In addition to the visible changes that burning causes to bone, the microscopic structure will also be affected. Recent methodological advances (e.g. Thompson et al. 2011, 2013) have allowed researchers to study these changes and use them to discuss contexts of burning. Fundamentally, bone is a crystalline structure in the form of hydroxyapatite $\left[\mathrm{Ca}_{10}\left(\mathrm{PO}_{4}\right)_{6}(\mathrm{OH})_{2}\right]$. Since this structure has a large-surface area, it makes it very reactive. Researchers have long been aware of this feature, and understanding this allows one to comment on diagenetic change or stable isotopic variation. Crucially this structural change is predictable, although the duration of this change can vary. In living individuals, bone has a disordered structure comprised of small crystals with large strain. When bone is burned, this structure transforms into one with larger, better ordered crystals with a smaller strain between them. Note that this transformation is not a linear process, but rather occurs 
slowly at lower intensity burning and then increases as the intensity of burning increases. Crystalline changes will ultimately plateau at around $1,000^{\circ} \mathrm{C}$.

Since this crystalline transformation is universal to all burning events, some bioarchaeologists attempted to correlate the degree of change with temperature of burning. Although there appears to be a solid correlation, the influence of uncontrolled and unknown variables on the nature of the burning event (i.e. oxygen availability, the presence of soft tissues, the use of accelerants, etc.) causes problems with the interpretation of results. Further complicating the widespread analysis and use of this correlation is the fact that different scientists use different methods or statistical techniques to examine this crystal change. One approach is to use X-ray Diffraction (XRD). This method allows one to examine the organisation of the crystal structure and has been used very successfully on burned bone (e.g. Enzo et al. 2007; Etok et al. 2007; Figueiredo et al. 2010; Rogers et al. 2010). Interestingly, some scientists have proposed that it is sensitive enough to speciate bone when burned (Beckett et al. 2011; Rogers et al. 2010; although also see Figueiredo et al. 2010 and Piga et al. 2013 for a counter argument). An alternative to the use of XRD is spectroscopy. Both Fourier transform infrared (FTIR) and Raman spectroscopy have been used to study burned bone, although the former is considerably more popular. Unlike XRD, spectroscopic methods examine the compounds that comprise the burned bone - which are a reflection of the crystal structure itself. In order to assess the degree of crystalline change using XRD or spectroscopy, it is necessary to use a statistical measure. One of the most discussed is the Crystallinity Index $(\mathrm{CI})$, which is used with the FTIR spectrometer in particular. The traditional $\mathrm{CI}$ is defined as $\mathrm{CI}=\left\{\mathrm{A}_{565}+\mathrm{A}_{605}\right\} / \mathrm{A}_{595}$, where $\mathrm{A}_{x}$ is the absorbance at given wavelength $x$. A baseline correction is usually applied between 750 and $450 \mathrm{~cm}^{-1}$ (Shemesh 1990; Thompson et al. 2011). Note that Thompson et al. (2013) recently suggested more appropriate calculations for assessing the degree of burning, while other scientists have used different equations to determine the same.

In the field, differences in heat-induced changes to crystallinity have been used in a variety of ways, such as to differentiate funerary practices, identify habitation sites and comment on pyre intensity (e.g. Butler and Dawson 2013; Piga et al. 2008; Schiegl et al. 2003; Squires et al. 2011). Generally these techniques seem to be most powerful when combined with other methods of analysis.

Burning has also been shown to alter the elemental composition of bone, and as with crystallinity changes described above, this is the result of the large highly-reactive surface area of bone microstructure. Despite some interest in the area (e.g. Grupe and Hummel 1991; Harbeck et al. 2011; Hummel et al. 1988), this remains the least well studied aspect of heat-induced change in bone - possibly because of the nature of the equipment and expertise required. Heat-induced changes in calcium, phosphorus, strontium, barium and lead have all been recorded, while changes in copper, zinc and magnesium seem to be independent of temperature (Grupe and Hummel 1991). Note that proportional changes in elements can also be the result of elemental uptake, but also the reduction in the organic phase (Grupe and Hummel 1991; Herrmann and Grupe 1988). Concentrations of elements have been used to determine whether bone has been burned or not, and in forensic contexts to state whether material presented to families from crematoria was actually bone (Brooks et al. 2006; Sillen and Hoering 1993). More recent work has focused on the impact of heating and burning on the results of radiocarbon and stable isotope analysis. With the former it has been shown that accurate dating is possible and that inter-laboratory accuracy is maintained with cremated bone (Olsen et al. 2007, 2013).

\subsection{Conclusion and Future Research}

Future work will need to address the problem of scattering and commingling in burned human skeletal remains, possibly following the work of Gonzalez-Rodriguez and Fowler (2013), who were 
able to discriminate the remains of several individuals using X-ray fluorescence and chemometric tools. Currently, bioarchaeologists and forensic anthropologists are quite powerless in doing this with cremated remains, therefore impacting on our methods of analysis (i.e. by limiting the range of our mass-related inferences). Another concern is related to method applicability. Current metric methods have large limitations. One reason for this is our inability to exactly assess the effect of heat-induced changes in a case-by-case basis. As a result, the selection of analytical methods can at times be ambiguous. Future research will necessarily have to address this question and eventually figure out a way of improving this important aspect of bioanthropological assessment of burned human skeletal remains. One means of addressing this is to combine methods, and refine the mapping between burn duration, intensity and the primary- and secondary-level heat-induced changes. This will enable more detailed investigation into the relative variation of bone change, which could indicate body position, tissue protection, combustion environment and exposure.

Overall the contribution of anthropologists, bioarchaeologists and forensic scientists to the study of burned and cremated human remains is increasing. Furthermore, the interpretations of these funerary and forensic contexts can be made with more confidence. This will continue as workers explore a greater range of burning contexts and practices.

\section{References}

Argáez, C., Batta, E., Mansilla, J., Pijoan, C. and Bosch, P. (2011) The origin of black pigmentation in a sample of Mexican prehispanic human bones. Journal of Archaeological Science, 38: 2979-2988.

Baby, R. (1954) Hopewell cremation practices. Papers in Archaeology, The Ohio Historical Society, 1: 1-7. Bass, W.M. and Jantz, R.L. (2004) Cremation weights in East Tennessee. Journal of Forensic Sciences, 49: 901-904.

Beach, J.J., Passalacqua, N.V. and Chapman, E.N. (2008) Heat-related changes in tooth color: temperature versus duration of exposure. In: Schmidt, C.W. and Symes, S.A. (eds), The Analysis of Burned Human Remains. Academic Press: London, pp. 137-144.

Beckett, S., Rogers, K.D. and Clement, J.G. (2011) Inter-species variation in bone mineral behaviour upon hearing. Journal of Forensic Sciences, 56: 571-579.

Bennett, B.L. (1999) Thermal alteration of buried bone. Journal of Archaeological Science, 26: 1-8.

Binford, L.R. (1963) An analysis of cremations from three Michigan sites. Wisconsin Archaeologist, 44: 98-110.

Bohnert, M., Rost, T. and Pollak, S. (1998) The degree of destruction of human bodies in relation to the duration of the fire. Forensic Science International, 95: 11-21.

Bohnert, M., Schmidt, U., Perdekamp, M.G. and Pollak, S. (2001) Extent of burn lesions: an analysis of 68 burned cadavers. Archiv für Kriminologie, 207: 104-113.

Bonucci, E. and Graziani, G. (1975) Comparative thermogravimetric, X-ray diffraction and electron microscope investigations of burnt bones from recent, ancient, and prehistoric age. Atti Memorie dell'Accademia Nazionale dei Lincei Scienze, Fisiche, Matematiche Naturali, Ser. 8 Sec. 2A, 59: 517-534.

Bradtmiller, B. and Buikstra, J.E. (1984) Effects of burning on human bone microstructure: a preliminary study. Journal of Forensic Sciences, 29: $535-540$.

Brooks, T.R., Bodkin, T.E., Potts, G.E. and Smullen, S.A. (2006) Elemental analysis of human cremains using ICP-OES to classify legitimate and contaminated cremains. Journal of Forensic Sciences, $\mathbf{5 1}$ 967-973. 
Butler, D.H. and Dawson, P.C. (2013) Accessing hunter-gatherer site structures using Fourier transform infrared spectroscopy: applications at a Taltheilei settlement in the Canadian Sub-Arctic. Journal of Archaeological Science, 40: $731-1742$.

Cattaneo, C., DiMartino, S., Scali, S., Craig, O.E., Grandi, M. and Sokol, R.J. (1999) Determining the human origin of fragments of burnt bone: a comparative study of histological, immunological and DNA techniques. Forensic Science International, 102: 181-191.

Chirachariyavej, T., Amnueypol, C., Sanggarnjanavanich, S. and Tiensuwan, M. (2006) The relationship between bone and ash weight to age, body weight and body length of Thai adults after cremation. Journal of the Medical Association of Thailand, 89: 1940-1945.

Collins, M.J., Nielsen-Marsh, C.M., Hiller, J., Smith, C.I., Roberts, J.P. et al. (2002) The survival of organic matter in bone: a review. Archaeometry, 44: 383-394.

DeHaan, J.D. (2002) Kirk's Fire Investigation. Brady Publishing: New York.

DeHaan, J.D. (2008) Fire and bodies. In: Schmidt, C.W. and Symes, S.A. (eds), The Analysis of Burned Human Remains. Academic Press: London, pp. 1-16.

DeHaan, J.D. and Nurbakhsh, S. (2001) Sustained combustion of an animal carcass and its implications for the consumption of human bodies in fires. Journal of Forensic Science, 46: 1076-1081.

Devlin, J.B. and Herrmann, N.P. (2008) Bone color as an interpretive tool of the depositional history of human cremains. In: Schmidt, C.W. and Symes, S.A. (eds), The Analysis of Burned Human Remains. Academic Press: London, pp. 109-128.

Duday, H. (2009) The Archaeology of the dead: Lectures in archaeothanatology. Oxbow Books: Oxford

Duday, H., Depierre, G. and Janin, T. (2000) Validation des paramètres de quantification, protocoles et stratégies dans l'étude anthropologique des sépultures secondaires à incinération. L'exemple des nécropoles protohistoriques du midi de la France. In : Dedet, B., Gruat, P., Marchand, G., Py, M. and Schwaller, M. (eds), Archéologie de la mort, archéologie de la tombe au premier Âge du Fer. AFEAF: Lattes, pp. 7-29.

Dunlop, J.M. (1978) Traffic light discolouration in cremated bones. Medicine, Science and The Law, 18: $163-173$.

Eckert, W.G., James, S. and Katchis, S. (1988) Investigation of cremations and severely burned bodies. American Journal of Forensic Medicine and Pathology, 9: 188-200.

Ellingham, S.T.D., Thompson, T.J.U., Islam, M. and Taylor, G. (2015) Estimating temperature exposure of burnt bone - A methodological review. Science and Justice, 55: 181-188.

Enzo, S., Bazzoni, M., Mazzarello, V., Piga, G., Bandiera, P. and Melis, P. (2007) A study by thermal treatment and X-ray powder diffraction on burnt fragmented bones from tombs II, IV and IX belonging to the hypogeic necropolis of 'Sa Figu' near Ittiri, Sassari (Sardinia, Italy). Journal of Archaeological Science, 34: 1731-1737.

Etok, S.E., Valsami-Jones, E., Wess, T.J., Hiller, J.C., Maxwell, C.A. et al. (2007) Structural and chemical changes of thermally treated bone apatite. Journal of Material Science, 42: 9807-9816.

Fairgrieve S (2008) Forensic Cremation: Recovery and analysis. CRC Press: Boca Raton.

Fernández Castillo, R., Ubelaker, D.H., Acosta, J.A.L. and de la Fuente, G.A.C. (2013a) Effects of temperature on bone tissue. Histological study of the changes in the bone matrix. Forensic Science International, 226: 33-37.

Fernández Castillo, R., Ubelaker, D.H., Acosta, J.A.L., de la Rosa, R.J.E. and Garcia, I.G. (2013b) Effect of temperature on bone tissue: histological changes. Journal of Forensic Sciences, 58: 578-582.

Figueiredo, M., Fernando, A., Martins, G., Freitas, J., Judas, F. and Figueiredo, H. (2010) Effect of the calcination temperature on the composition and microstructure of hydroxyapatite derived from human and animal bone. Ceramics International, 36: 2383-2393.

Forbes, G. (1941) The effects of heat on the histological structure of bone. Police Journal, 14: 50-60. 
Gonçalves, D. (2012) Cremains: The value of quantitative analysis for the bioanthropological research of burned human skeletal remains. Unpublished PhD thesis. University of Coimbra: Coimbra.

Gonçalves, D., Campanacho, V., Thompson, T.J.U., Cunha, E. and Mataloto, R. (2015) The weight of the matter: examining the potential of skeletal weight for the bioarchaeological analysis of cremation at the Iron Age necropolis of Tera (Portugal). In: Thompson, T.J.U. (ed.), The Archaeology of Cremation: Burned human remains in funerary studies. Oxbow Books: Oxford, pp. 63-96.

Gonçalves, D., Thompson, T.J.U. and Cunha, E. (2011) Implications of heat-induced changes in bone on the interpretation of funerary behaviour and practice. Journal of Archaeological Science, 38: $1308-1313$.

Gonçalves, D., Cunha, E. and Thompson, T.J.U. (2013a) Weight references for burned human skeletal remains from Portuguese samples. Journal of Forensic Sciences, 58: 1134-1140.

Gonçalves, D., Thompson, T.J.U. and Cunha, E. (2013b) Osteometric sex determination of burned human skeletal remains. Journal of Forensic and Legal Medicine, 20: 906-911.

Gonzalez-Rodriguez, J. and Fowler, G. (2013) A study on the discrimination of human skeletons using $\mathrm{X}$-ray fluorescence and chemometric tools in chemical anthropology. Forensic Science International, 231: 407.e401-406.

Grupe, G. and Herrmann, B. (1983) Über das schrumpfungsverhalten experimentell verbrannter spongiöser knochen am beispiel des caput femoris. Zeitschrift für Morphologie und Anthropologie, 74: $121-127$.

Grupe, G. and Hummel, S. (1991) Trace element studies on experimentally cremated bone. I. Alteration of the chemical composition at high temperatures. Journal of Archaeological Science, 18: 177-186.

Hanson, M. and Cain, C.R. (2007) Examining histology to identify burned bone. Journal of Archaeological Science, 34: 1902-1913.

Harbeck, M., Schleuder, R., Schneider, J., Wiechmann, I., Schmahl, W.W. and Grupe, G. (2011) Research potential and limitations of trace analyses of cremated remains. Forensic Science International, 204: $191-200$.

Harvig, L., Kveiborg, J. and Lynnerup, N. (2013) Death in flames. human remains from a domestic house fire from Early Iron Age, Denmark. International Journal of Osteoarchaeology, 25: 701-710.

Herrmann, B. (1976) Experimentelle und theoretische beiträge zur leichenbrand unter schung. Homo, 27: $114-118$.

Herrmann, B. (1977) On histological investigations of cremated human remains. Journal of Human Evolution, 6: 101-103.

Herrmann, B. and Grupe, G. (1988) Trace element content in prehistoric cremated human remains. In: Grupe, G. and Herrmann, B. (eds), Trace Elements in Environmental History. Proceedings of the Symposium held 24-26 June 1987 at Göttingen. Springer-Verlag: Berlin, pp. 91-101.

Hiller, J.C., Thompson, T.J.U., Evison, M.P., Chamberlain, A.T. and Wess, T.J. (2003) Bone mineral change during experimental heating: an X-ray scattering investigation. Biomaterials, 24: 5091-5097.

Holland, T.D. (1989) Use of the cranial base on the identification of fire victims. Journal of Forensic Sciences, 34: 458-460.

Hummel, S., Schutkowski, H. and Herrmann, B. (1988) Advances in cremation research. Actes des 3èmes Journées Anthropologiques, 24: 177-194.

Karr, L.P. and Outram, A.K. (2012) Bone degradation and environment: understanding, assessing and conducting archaeological experiments using modern animal bones. International Journal of Osteoarchaeology, 25: 201-212.

Kennedy, K.A.R. (1996) The wrong urn: commingling of cremains in mortuary practices. Journal of Forensic Sciences, 41: 689-692.

Kharkanis, S., Ball, J. and Franklin, D. (2009) macroscopic and microscopic changes in incinerated deciduous teeth. Journal of Forensic Odontostomatology, 27: 9-19. 
Lenorzer, S. (2006) Pratiques funéraires du Bronze final IIIb au premier âge du Fer en Languedoc occidental et Midi-Pyrénées: Approche archéo-anthropologique des nécropoles à incinération. Unpublished PhD thesis. University of Bordeaux: Bordeaux.

Lynnerup, N. (2010) Medical imaging of mummies and bog bodies, a mini-review. Gerontology, 56: $441-448$.

Malinowski, A. and Porawski, R. (1969) Identifikations Möglichkeiten menschlicher Brandknochen mit besonder Berücksichtigung ihres Gewichts. Zacchia, 5: 1-19.

May, S.E. (2011) The effects of body mass on cremation weight. Journal of Forensic Sciences, 56: 3-9.

Mayne Correira, P. (1997) Fire modification of bone: a review of the literature. In: Haglund, W.D. and Sorg, M.H. (eds), Forensic Taphonomy: The postmortem fate of human remains. CRC Press: Boca Raton, pp. 275-293.

McCutcheon, P.T. (1992) Burned archaeological bone. In: Stein, J.K. (ed.), Deciphering a Shell Midden. Academic Press: London, pp. 347-370.

McKinley, J.I. (1993) Bone fragment size and weights of bone from British cremations and the implications for the interpretation of archaeological cremations. International Journal of Osteoarchaeology, 3: 283-287.

McKinley, J.I. (1994) The Anglo-Saxon Cemetery at Spong Hill, North Elmham. Part VIII: The cremations. East Anglian Archaeology Report 69, Norfolk Museums Service: Dereham.

McKinley, J.I. (2000) The analysis of cremated bone. In: Cox, M. and Mays, S. (eds), Human Osteology: In archaeology and forensic science. Cambridge University Press: Cambridge, pp. 403-421.

Munro, L.E., Longstaffe, F.J. and White, C.D. (2007) Burning and boiling of modern deer bone: effects on crystallinity and oxygen isotope composition of bioapatite phosphate. Palaeogeography, Palaeoclimatology, Palaeoecology, 249: 90-102.

Nicholson, R.A. (1993) A morphological investigation of burnt animal bone and an evaluation of its utility in archaeology. Journal of Archaeological Science, 20: 411-428.

Oakley, K. (1954) Evidence of fire in South African cave deposits. Nature, 174: 261-262.

Olsen, J., Heinemeier, J., Bennike, P., Krause, C., Hornstrup, K.M. and Thrane, H. (2007) Characterisation and blind testing of radiocarbon dating of cremated bone. Journal of Archaeological Science, 35: $791-800$.

Olsen, J., Heinemeier, J., Hornstrup, K.M., Bennike, P. and Thrane, H. (2013) 'Old wood' effect in radiocarbon dating of prehistoric cremated bones? Journal of Archaeological Science, 40: 30-34.

Person, A., Bocherens, H., Mariotti, A. and Renard, M. (1996) Diagenetic evolution and experimental heating of bone phosphate. Palaeogeography, Palaeoclimatology, Palaeoecology, 126: 135-149.

Piepenbrink, H. (1986) Two examples of biogenous dead bone decomposition and their consequences for taphonomic interpretation. Journal of Archaeological Science, 13: 417-430.

Piga, G., Guirguis, M., Bartoloni, P., Malgosa, A. and Enzo, S. (2008) A funerary rite study of the Phoenician-Punic necropolis of Mount Sirai (Sardinia, Italy). International Journal of Osteoarchaeology, 18: 1-14.

Piga, G., Solinas, G., Thompson, T.J.U., Brunetti, A., Malgosa, A. and Enzo, S. (2013) Is X-ray diffraction able to distinguish between animal and human bones? Journal of Archaeological Science, 40: 778-778.

Richier, A. (2005) Sépultures primaires à incineration: nouvelles données et nouvelles problématiques. In: Mordant, C. and Depierre, G. (eds), Les pratiques funéraires à l'âge du bronze en France. Comité des Travaux Historiques et Scientifiques: Paris, pp. 199-210.

Rogers, K.D., Beckett, S., Kuhn, S., Chamberlain, A. and Clement, J. (2010) Contrasting the crystallinity indicators of heated and diagenetically altered bone mineral. Palaeogeography, Palaeoclimatology, Palaeoecology, 296: 125-129.

Roberts, S.J., Smith, C.I., Millard, A.R. and Collins, M.J. (2002) The taphonomy of cooked bone: characterizing boiling and its physico-chemical effects. Archaeometry, 44: 485-494. 
Sandholzer, M.A., Walmsley, A.D., Lumley, P.J. and Landini, G. (2013) Radiologic evaluation of heat-induced shrinkage and shape preservation of human teeth using micro-CT. Journal of Forensic Radiology and Imaging, 1: $107-111$.

Sandholzer, M.A. (2014) Heat-induced Alterations of Dental Tissues. Unpublished PhD Thesis. University of Birmingham: Birmingham.

Sandholzer, M.A., Baron, K., Heimel, P. and Metscher, B.D. (2014) Volume analysis of heat-induced cracks in human molars: A preliminary study. Journal of Forensic Dental Science, 6: 139-44.

Schiegl, S., Goldberg, P., Pfretzschner, H.-U. and Conard, N.J. (2003) Paleolithic burnt bone horizons from the Swabian Jura: distinguishing between in situ fireplaces and dumping areas. Geoarchaeology: An International Journal, 18: 541-565.

Schmidt, C.W. (2008) The recovery and study of burned human teeth. In: Schmidt, C.W. and Symes, S.A. (eds), The Analysis of Burned Human Remain. Academic Press: London, pp. 55-74.

Schwark, T., Heinrich, A., Preusse-Prange, A. and Von Wurmb-Schwark, N. (2011) Reliable genetic identification of burnt human remains. Forensic Science International: Genetics, 5: 393-399.

Shahack-Gross, R., Bar-Yosef, O. and Weiner, S. (1997) Black-colored bones in Hayorim Cave, Israel: differentiating between burning and oxide staining. Journal of Archaeological Science, 24: 439-446.

Shemesh, A. (1990) Crystallinity and diagenesis of sedimentary apatites. Geochimica et Cosmochimica Acta, 54: 2433-2438.

Shipman, P., Foster, G. and Schoeninger, M. (1984) Burnt bones and teeth: an experimental study of colour, morphology, crystal structure and shrinkage. Journal of Archaeological Science, 11: 307-325.

Sillen, A. and Hoering, T. (1993) Chemical characterization of burnt bones from Swartkrans. In: Brain, C.K. (ed.), Swartkrans: a cave's chronicle of early man. Transvaal Museum Monograph 8: Pretoria, pp. $243-249$

Silve, C. and Jüppner, H. (2006) Ollier disease. Orphanet Journal of Rare Diseases, 1: 37.

Squires, K.E. (2011) An Osteological Analysis and Social Investigation of the Cremation Rite at the Cemeteries of Elsham and Cleatham, North Lincolnshire. Unpublished PhD thesis. University of Sheffield: Sheffield.

Squires, K.E. (2015) The use of microscopic techniques in cremation studies: A new approach to understanding the social identity of cremation practicing groups from early Anglo-Saxon England. In: Thompson, T.J.U. (ed.), The Archaeology of Cremation: Burned human remains in funerary studies. Oxbow Books: Oxford.

Squires, K.E., Thompson, T.J.U., Islam, M. and Chamberlain, A. (2011) The application of histomorphometry and Fourier Transform Infrared Spectroscopy to the analysis of early Anglo-Saxon burned bone. Journal of Archaeological Science, 38: 2399-2409.

Stiner, M.C., Kuhn, S.L., Weiner, S. and Bar-Yosef, O. (1995) Differential burning, recrystallization and fragmentation of archaeological bone. Journal of Archaeological Science, 22: 223-237.

Strzalko, J. and Piontek, J. (1974) Wpływ spalania w warunkach zbliżonych do kremacji pradziejowych na morfologię kości. Przeglad Antropologiczny, 40: 315-326.

Subías, S.M. (2002) Cooking in Zooarchaeology: Is this issue still raw? In: Miracle, P. and Milner, N. (eds), Consuming Passions and Patterns of Consumption. McDonald Institute of Archaeological Research: Cambridge, pp. $7-15$.

Svensson, A. and Wendel, O. (1965) The Techniques of Crime Scene Investigation. New York: Elsevier.

Symes, S.A., Rainwater, C., Chapman, E., Gipson, D.R. and Piper, A. (2008) Patterned thermal destruction of human remains in a forensic setting. In: Schmidt, C.W. and Symes, S.A. (eds), The Analysis of Burned Human Remains. Academic Press: London, pp. 15-54.

Thompson, T.J.U. (2004) Recent advances in the study of burned bone and their implications for forensic anthropology. Forensic Science International, 146: S203-S205. 
Thompson, T.J.U. (2005) Heat-induced dimensional changes in bone and their consequences for forensic anthropology. Journal of Forensic Sciences, 50: 185-193.

Thompson, T.J.U. (2009) Burned human remains. In: Blau, S. and Ubelaker, D. (eds), Handbook of Forensic Anthropology and Archaeology. Left Coast Press: Walnut Creek, pp. 295-303.

Thompson, T.J.U., Islam, M. and Bonniere, M. (2013) A new statistical approach for determining the crystallinity of heat-altered bone mineral from FTIR spectra. Journal of Archaeological Science, 40: 416-422.

Thompson, T.J.U., Islam, M., Piduru, K. and Marcel, A. (2011) An investigation into the internal and external variables acting on Crystallinity Index using Fourier Transform Infrared Spectroscopy on unaltered and burned bone. Palaeogeography, Palaeoclimatology, Palaeoecology, 299: 168-174.

Thompson, T.J.U. (2015) The Archaeology of Cremation: Burned human remains in funerary studies. Studies in Funerary Archaeology Series, Oxbow Press: Oxford.

Thurman, M. and Wilmore, L. (1980) A replicative cremation experiment. North American Archaeologist, 2: $275-283$.

Ubelaker, D. (1978) Human Skeletal Remains: Excavation, analysis, interpretation. Aldine: Chicago, IL.

Ulguim, P.F. (2015) Analysing cremated human remains from the southern Brazilian highlands: Interpreting archaeological evidence of funerary practice at mound and enclosure complexes in the Pelotas River Valley. In: Thompson, T.J.U. (ed.), The Archaeology of Cremation: Burned human remains in funerary studies. Oxbow Press: Oxford.

Van Deest, T.L., Murhad, T.A. and Bartelink, E.J .(2011) A re-examination of cremains weight: sex and age variation in a Northern Californian sample. Journal of Forensic Sciences, 56: 344-349.

Van Vark, G.N. (1974) The investigation of human cremated skeletal material by multivariate statistical methods I. Methodology. Ossa, 1: 63-95.

Van Vark, G.N., Amesz-Voorhoeve, W. and Cuijpers, A. (1996) Sex-diagnosis of human cremated skeletal material by means of mathematical-statistical and data-analytical methods. Homo, 47: 305-338.

Wahl, J.K. (1996) Erfahrungen zur metrishen Geschlechtsdiagnose bei Leichenbränden. Homo, 47: 339-359.

Waldron, T. (2009) Palaeopathology. Cambridge University Press: Cambridge

Walker, P.L. and Miller, K.W.P. (2005) Time, temperature, and oxygen availability: an experimental study of the effects of environmental conditions on the color and organic content of cremated bone. American Journal of Physical Anthropology, 40: 222.

Walker, P.L., Miller, K.W.P. and Richman, R. (2008) Time, temperature, and oxygen availability: an experimental study of the effects of environmental conditions on the color and organic content of cremated bone. In: Schmidt, C.W. and Symes, S.A. (eds), The Analysis of Burned Human Remains. Academic Press: London, pp. 129-135.

Warren, M.W. (2008) Detection of commingling in cremated human remains. In: Adams, B.J. and Byrd, J.E. (eds), Recovery, Analysis, and Identification of Commingled Human Remains. Humana Press: Totowa, pp. 185-197.

Warren, M.W. and Maples, W.R. (1997) The anthropometry of contemporary commercial cremation. Journal of Forensic Sciences, 42: 417-423.

Wolf, A. (2011) Determining whether Spectrophotometer CIE L*a*b* Color Analysis is an Effective Alternative to Munsell Soil Color Charts for the Study Of Burnt Bones: Insights from analysis of Babedh-Dhra EB II-III Burnt Bone. Unpublished Honours Thesis. Oberlin College: Oberlin. 